\title{
ANALISIS PENGGUNAAN TATA BAHASA DAN PEMEROLEHAN BAHASA KEDUA BAHASA INGGRIS PADA MAHASISWA THAILAND
}

\author{
Minkhatunnakhriyah, Fahriany, Albiansyah \\ minkhatun.riyah@gmail.com \\ Universitas Islam Negeri Syarif Hidayatullah, Jakarta
}

\begin{abstract}
This paper aims to determine the types of grammar usage and to describe the acquisition of English as a second language among Thai students. The method used was a qualitative paradigm and the data sources were taken from interviews. The interview instrument was used to obtain the data in the form of English text production, which was used to identify and to classify the types of grammar elements and information on how informants acquire the language. This study results in variations in the use of grammar elements namely simple present tense, simple past tense, degree of comparison, noun phrases, and auxiliary verbs. The results of the interview show that the process of mastery of a second language was obtained through watching films in English or films with English subtitles, reading novels in English, and listening to English songs.
\end{abstract}

Keywords: English Grammar, Second Language Acquisition, Speaking

Bahasa adalah alat komunikasi utama dalam kehidupan manusia yang disampaikan melalui ucapan, pikiran, dan perasaan. Selanjutnya fungsi utama bahasa adalah sebagai alat komunikasi dan interaksi yang hanya dimiliki oleh manusia. Dengan demikian, untuk dapat berkomunikasi manusia harus menguasai bahasa. Menurut Wasow (2017) bahasa merupakan fenomena alam yang merupakan bagian tak terpisahkan dari setiap kebudayaan manusia. Dalam teori pemerolehan bahasa dikenal istilah bahasa pertama dan bahasa kedua. Bahasa pertama atau disebut pula dengan bahasa ibu merupakan bahasa utama yang diperoleh pada usia dini dengan meniru dari lingkungan itu sendiri, sedangkan bahasa kedua dapat diperoleh dan dikuasai hanya dengan belajar secara sadar dan sengaja. Menurut Shirai (2018), tujuan dari bahasa kedua adalah untuk memahami proses pemerolehan bahasa. Hal ini sejalan dengan Bolton (2018) yang menyatakan bahwa tujuan pemerolehan bahasa kedua adalah untuk mengembangkan kemampuan seperti penutur asli. Jadi, proses pemerolehan bahasa kedua membutuhkan motivasi yang tinggi. 
Namun pada kenyataannya, ketika seseorang menggunakan bahasa kedua untuk berkomunikasi, ia hanya menyampaikan maksud apa yang ia sampaikan tanpa memperhatikan susunan kalimatnya. Di samping itu, ketika menggunakan bahasa kedua, secara tidak sadar ada inferensi dari bahasa pertama. Seperti yang dinyatakan oleh Derakhshan (2015) seseorang yang belajar bahasa kedua pasti mengalami inferensi dari bahasa pertama baik dalam lisan maupun tulisan. Begitu pula menurut Beardsmore (1982) bahwa intervensi kebiasaan menggunakan bahasa pertama (L1) disebabkan siswa mengalami masalah dengan aspek menggunakan bahasa yang kedua (L2) seperti fonologi, kosakata, dan tata bahasa. Artinya intervensi bahasa merupakan kebiasaan bahasa dan kapasitas bahasa ibu. Oleh karena itu, ia harus memiliki kompetensi tata bahasa untuk membangun kompetensi komunikatif. Tata bahasalah yang membuat kalimat dapat dimaknai, karena susunan kata yang tidak benar atau tidak lazim dalam kalimat akan menjadikan orang sulit memahaminya. Orang yang menguasai tata bahasa akan dapat dengan mudah menyampaikan pesannya dan dapat dengan mudah pula dipahami oleh pendengarnya. Seperti yang dikemukakan oleh Dakin (2018), peran tata bahasa adalah memberikan prediksi seberapa baik seorang pembelajar mampu berkomunikasi dalam bahasa Inggris secara struktural.

Penelitian ini mengkaji bagaimana seseorang (informan) menggunakan tata bahasa dalam bahasa keduanya agar dapat berkomunikasi dengan orang di sekitarnya yang tidak menguasai bahasa pertama informan. Informan penelitian, yang sekaligus menjadi informan adalah Asmah Senkhao, mahasiswa berusia 25 tahun berasal dari Thailand. Informan saat ini sedang belajar bahasa Inggris di Universitas Islam Assyafi'iyyah Bekasi. Peneliti mengkaji unsur tata bahasa yang digunakan dan bagaimana pengalaman informan dalam pemerolehan bahasa keduanya, yakni bahasa Inggris. Seperti diketahui bahwa di Thailand bahasa Melayu (Melayu Thailand) juga menjadi bahasa pertama, dan bahasa kedua adalah bahasa Inggris.

Dalam kajian pemerolehan bahasa, bahasa digolongkan menjadi 3 macam, yaitu bahasa pertama, bahasa kedua, dan bahasa asing. Bahasa pertama adalah bahasa yang dipelajari seseorang sejak lahir atau dalam periode kritis, atau yang paling baik dikuasai dan digunakan seseorang serta sering kali menjadi dasar identitas Copyright $\odot 2021$ Minkhatunnakhriyah, Fahriany, Albiansyah 
Minkhatunnakhriyah, Fahriany, Albiansyah, Analisis Penggunaan Tata Bahasa dan Pemerolehan Bahasa Kedua Bahasa Inggris pada Mahasiswa Thailand

sosiolinguistik. Bahasa pertama disebut juga bahasa ibu, atau L1. Bahasa kedua adalah bahasa yang bukan bahasa ibu, tetapi digunakan untuk komunikasi publik. Dengan kata lain bahasa kedua adalah bahasa nonasli yang secara resmi diakui dan diadopsi di negara multibahasa sebagai alat komunikasi publik. Bahasa asing adalah bahasa asli negara lain. Ini juga merupakan bahasa yang tidak digunakan di negara asal orang yang dirujuk. Terdapat perbedaan antara bahasa pertama dan bahasa kedua atau bahasa asing. Bahasa pertama dipelajari oleh seorang anak di rumah, biasanya dari orang tuanya. Ini biasanya diperoleh pada periode penting perkembangan kognitif; prapubertas. Bahasa kedua dipelajari oleh seorang anak setelah dia mendapatkan bahasa pertamanya. Bahasa kedua tidak dipelajari sebagai bagian dari perkembangan kognitif umum dan bukan merupakan kecakapan hidup yang esensial seperti halnya bahasa pertama.

\section{Pemerolehan Bahasa Kedua}

Fungsi penguasaan bahasa kedua terhadap akademisi atau pelajar yaitu untuk mendukung pengetahuan mereka. Beberapa ahli mendefinisikan pemerolehan bahasa kedua. Krashen (2002) menyatakan bahwa penguasaan bahasa kedua mengacu pada studi tentang bagaimana siswa mempelajari bahasa kedua selain bahasa pertama mereka. Lebih lanjut menurut Chaer (2009), pemerolehan bahasa merupakan suatu proses yang berlangsung di dalam otak seseorang. Penguasaan bahasa biasanya dibedakan dari pembelajaran bahasa.

Ada dua proses yang terjadi ketika seseorang mempelajari bahasa pertamanya, yaitu proses kompetensi dan proses kinerja (Chaer, 2009). Proses kompetensi merupakan proses penguasaan tata bahasa yang berjalan tanpa disadari. Selanjutnya proses kinerja terdiri atas dua proses yaitu proses memahami dan proses menghasilkan kalimat. Sejalan dengan teori Chomsky (1972), kompetensi mencakup tiga komponen tata bahasa, yaitu komponen sintaksis, komponen semantik, dan komponen fonologis. Oleh karena itu, pemerolehan bahasa ini juga biasanya dibagi menjadi pemerolehan 
semantik, sintaksis, dan fonologis. Berdasarkan penjelasan tersebut, terdapat beberapa teori atau hipotesis yang berkaitan dengan masalah penguasaan bahasa.

\section{Gangguan Bahasa}

Transfer bahasa juga dikenal sebagai interferensi bahasa pertama (L1). Interferensi linguistik mengacu pada penutur atau penulis yang menerapkan pengetahuan dari bahasa ibu ke bahasa kedua. Dulay dkk. (1982) mendefinisikan interferensi bahasa sebagai transfer otomatis karena kebiasaan dari struktur bahasa pertama ke bahasa target ketika seseorang memahami satu bahasa. Hal itu berdampak pada pemahamannya tentang bahasa lain; artinya, individu tersebut mengalami transfer bahasa. Dalam proses ini mungkin terjadi transfer negatif, atau dikenal sebagai gangguan ketika pemahaman satu bahasa mempersulit pemahaman bahasa lain. Sebaliknya, transfer positif juga bisa terjadi sehingga pengetahuan mengenai satu bahasa dapat membantu mengembangkan keterampilan bahasa kedua.

Terdapat pengaruh gangguan bahasa terhadap aspek lain, misalnya tata bahasa, kosakata, aksen, maupun ejaan. Jadi, gangguan bahasa dianggap sebagai salah satu sumber kesalahan atau transfer negatif, meskipun fitur yang relevan dari kedua bahasa itu sama. Hal tersebut menghasilkan produksi bahasa yang benar atau transfer positif. Jadi, dapat disimpulkan bahwa semakin besar perbedaan dengan dua bahasa, semakin negatif kemungkinan efek interferensi. Ini pasti akan terjadi dalam situasi apa pun di mana seseorang belum menguasai bahasa kedua.

\section{Tata Bahasa}

Tata bahasa adalah cara untuk berkomunikasi yang efektif. Selain itu, tata bahasa yang tidak tepat dapat memberikan pengaruh terhadap makna dan kejelasan suatu pesan yang membuatnya tidak dapat dimengerti. Berdasarkan Thornbury (1999), tata bahasa adalah studi konvensional tentang sintaksis dan morfologi dalam kalimat, Tetapi di sisi lain, tata bahasa termasuk linguistik. Peserta didik tidak hanya belajar untuk membuat kalimat akan tetapi untuk memahami makna tertentu. Ada dua arti dan tujuan utama bahasa, yaitu fungsi representasi dan interpersonal bahasa. 
Minkhatunnakhriyah, Fahriany, Albiansyah, Analisis Penggunaan Tata Bahasa dan Pemerolehan Bahasa Kedua Bahasa Inggris pada Mahasiswa Thailand

Ketika orang memproses suatu bahasa, ia tidak hanya mencoba untuk memahami kata pada tata bahasa tetapi juga mencoba untuk menyimpulkan maksud (tertulis) pembicara. Selain itu, tata bahasa yang tepat juga penting untuk memahami bahasa Inggris sebagai bahasa kedua serta untuk mempelajari bahasa baru, karena semua bahasa mengikuti pola tata bahasa. Sebagai contoh, dengan Amerika Serikat menjadi tempat meleburnya kebangsaan dan penutur bahasa asing, mendengar bahasa Inggris yang tepat dan konsisten sangat membantu untuk mendorong setiap pendatang baru di negara tersebut menjadi fasih. Hal ini akan membantu penutur asli bahasa Inggris dalam memahami dialek lain juga.

\section{Berbicara}

Berbicara merupakan suatu cara mengungkapkan pendapat. Ini adalah arti sederhana dari berbicara. Dalam arti luas berbicara memiliki ruang lingkup yang cukup dalam. Menurut Nunan (1991) berbicara digambarkan sebagai aktivitas kemampuan untuk mengekspresikan diri dalam situasi, atau aktivitas dengan kata-kata yang tepat, atau kemampuan untuk berbicara, dan mengungkapkan urutan ide dengan lancar. Lebih lanjut Tarigan (1990) mengatakan bahwa berbicara adalah cara berkomunikasi yang berpengaruh dalam kehidupan sehari-hari. Artinya, berbicara adalah kegiatan untuk berkomunikasi yang sangat berpengaruh dalam kehidupan seseorang. Maka, dapat disimpulkan bahwa berbicara merupakan salah satu jenis keterampilan berbahasa.

\section{METODE}

Penelitian ini menggunakan penelitian deskripsi kualitatif. Data dikumpulkan melalui teknik wawancara dari informan penelitian, yakni seorang mahasiswa Thailand. Data wawancara digunakan sebagai sumber informasi bagaimana pemerolehan bahasa kedua informan dan sebagai sumber analisis dalam menentukan variasi tata bahasa yang digunakan oleh informan. 


\section{HASIL DAN PEMBAHASAN}

\section{Proses Memperoleh Tata Bahasa Inggris pada Mahasiswa Asing dari Thailand}

Dari hasil wawancara, diketahui bahwa pemerolehan bahasa kedua informan diperoleh melalui aktivitas mendengarkan lagu-lagu bahasa Inggris, menonton film dengan subtitle, bahasa Inggris, dan membaca novel berbahasa Inggris.

"my process to enhance my English, I have new vocabulary everyday then I listen English songs, watch movie by English subtitle, I think it is the best way for my study".

"Cara untuk meningkatkan bahasa Inggris saya, biasanya dengan menambah kosakata setiap hari melalui mendengarkan musik berbahasa Inggris kemudian menonton film. Menurut saya, itu proses yang terbaik untuk memperoleh bahasa kedua saya yaitu bahasa Inggris".

Ketika peneliti mewawancarai informan, dia mencoba berbicara bahasa Inggris secara tata bahasa. Jadi, terkadang, dia mengucapkan dengan lambat ketika dia berbicara bahasa Inggris. Dia mengatakan bahwa:

"sometime I still confuse to produce my English because it is my new language and I need study harder likes I memorizing vocabulary in every day, reading some novel in English language".

"Kadang-kadang saya masih bingung untuk berbicara bahasa Inggris karena ini adalah bahasa baru dan saya perlu belajar lebih keras seperti menghafal kosakata setiap hari, membaca beberapa novel dalam bahasa Inggris."

Dari penggunaan tata bahasa Inggris dalam bertuturnya, ia selalu berusaha untuk meningkatkan kemampuan berbicara dalam bahasa Inggris melalui menghafal kosakata, mendengarkan musik berbahasa Inggris, dan mempraktikkannya.

\section{Jenis penggunaan tata bahasa Inggris dalam berbicara}

Dari data diperoleh beberapa jenis tata bahasa yang digunakan dalam tuturan informan yang dikodekan oleh peneliti melalui hasil wawancara pertanyaan pertama “Apa yang biasanya kamu lakukan di hari Minggu?" 
Minkhatunnakhriyah, Fahriany, Albiansyah, Analisis Penggunaan Tata Bahasa dan Pemerolehan Bahasa Kedua Bahasa Inggris pada Mahasiswa Thailand

Tabel 1. Penggunaan Simple Present Tense

\begin{tabular}{|c|c|c|c|c|}
\hline Nomor & $\begin{array}{l}\text { Jenis } \\
\text { Penggunaan } \\
\text { Tata Bahasa }\end{array}$ & Struktur & Kalimat & Total \\
\hline \multirow{4}{*}{1} & \multirow{4}{*}{ Simple Present } & \multirow{4}{*}{$\mathrm{S}+\mathrm{V} 1+\mathrm{O}$} & $\begin{array}{l}\text { Saya hanya tinggal di asrama, dan sering sarapan } \\
\text { pagi. } \\
\text { (I stay in dormitory and I often to breakfast) }\end{array}$ & \multirow{4}{*}{5} \\
\hline & & & $\begin{array}{l}\text { Biasanya, saya bangun pukul } 04.00 \\
\text { (Usually I get up at } 4 \text { AM) }\end{array}$ & \\
\hline & & & $\begin{array}{l}\text { Saya menonton film Korea. } \\
\text { (I watch Korean movie) }\end{array}$ & \\
\hline & & & $\begin{array}{l}\text { Biasanya, saya mendengarkan musik berbahasa } \\
\text { Inggris } \\
\text { (Occasionally, I listen to English song) }\end{array}$ & \\
\hline
\end{tabular}

Tabel 1 menunjukkan bahwa informan memahami tata bahasa yang harus digunakan terkait dengan konteks pertanyaan. Kemudian ia mengetahui struktur simple present tense adalah penggunaan $V I+O$ dan ia menggunakan struktur negatif yang sesuai melalui penggunaan auxiliary $D O+N O T$ seperti tampak pada kutipan berikut:

"I think, I stay in dormitory and I often to breakfast. Usually, I get up at 4AM. I watch Korean movie, because e... first time I do not like but sometimes my friend, she watches Korean movie then I like".

"Saya pikir saya tinggal di asrama dan saya sering sarapan. Biasanya saya bangun pukul 4 pagi. Saya menonton film Korea, karena e... pertama kali saya tidak suka tapi kadang-kadang teman saya, dia menonton film Korea lalu saya suka”.

Tabel 2. Penggunaan Degree of comparison, Noun Phrase, dan Auxiliary Verbs

\begin{tabular}{|c|c|c|c|c|}
\hline Nomor & $\begin{array}{c}\text { Jenis Penggunaan Tata } \\
\text { Bahasa }\end{array}$ & Struktur & Kalimat & Total \\
\hline 2 & Degree of comparison & $\mathrm{S}+($ Tobe $)+\underset{O}{\text { Adj }}+\mathrm{er}+$ Than + & $\begin{array}{l}\text { Dia lebih tinggi dariku. } \\
\text { (He is taller than me.) } \\
\text { adik laki-laki ku } \\
\text { (my younger brother) }\end{array}$ & 2 \\
\hline 3 & Noun Phrase & Adj + Noun & $\begin{array}{l}\text { Dia berkulit putih. } \\
\text { (He is white skin.) } \\
\text { Dia adalah anak laki-laki } \\
\text { yang tampan. } \\
\text { (He is handsome boy.) }\end{array}$ & 2 \\
\hline 4 & Auxiliary Verb & Auxiliary verb (Do) & $\begin{array}{l}\text { Dia ingin menjadi pemain } \\
\text { sepak bola. } \\
\text { (He wants to be football } \\
\text { player.) } \\
\text { dia berkulit putih } \\
\text { (He is white skin) }\end{array}$ & 3 \\
\hline
\end{tabular}


Pertanyaan kedua dari wawancara adalah mengenai deskripsi keluarga informan di Thailand. Saat mendeskripsikan keluarganya, ia mampu menggunakan tata bahasa dengan benar misalnya dalam bentuk degree of comparison dan adjective.

Tabel 2 menunjukkan bahwa informan dapat menggunakan bahasa kedua dengan memperhatikan penggunaan tata bahasa dengan baik dan benar. Selain itu, ia telah mengetahui ketika ingin mengungkapkan bentuk perbandingan, ia mengetahui struktur di dalamnya, begitu pula penggunaan frase nomina dan verba pembantu. Hal ini dapat dilihat pada kutipan berikut:

' $y E$ '...my brother., and he is white skin, he is handsome and he likes play football. He wants to be football player".

"Ya... saudaraku., dan dia berkulit putih, dia tampan, dan dia suka bermain sepak bola. Dia ingin menjadi pemain sepak bola".

Pertanyaan terakhir yaitu tentang pengalamannya kenapa dia ingin kuliah di Indonesia. Berbicara tentang konteks pengalaman berarti membicarakan peristiwa masa lalu yang harus menggunakan bentuk kala lampau dan menggunakan verba dua (V2) dalam penuturannya. Hal ini dapat dilihat pada Tabel 3:

Tabel 3. Penggunaan Simple Past Tense

\begin{tabular}{|c|c|c|c|c|}
\hline Nomor & $\begin{array}{l}\text { Jenis Penggunaan } \\
\text { Tata Bahasa }\end{array}$ & Struktur & Kalimat & Total \\
\hline \multirow{6}{*}{5} & \multirow{6}{*}{ Simple Past } & \multirow{6}{*}{$\mathrm{S}+\mathrm{V} 2+\mathrm{O}$} & $\begin{array}{l}\text { ketika saya masih di Thailand } \\
\text { (when I was in Thailand) }\end{array}$ & \multirow{6}{*}{6} \\
\hline & & & $\begin{array}{l}\text { Saya ingin belajar di Malaysia dan Turki. } \\
\text { (I wanted to study at Malaysia and Turkey) }\end{array}$ & \\
\hline & & & $\begin{array}{l}\text { tapi Turki itu jauh dari Thailand } \\
\text { (but turkey was far away from Thailand) }\end{array}$ & \\
\hline & & & $\begin{array}{l}\text { Malaysia sangat mahal. } \\
\text { (Malaysia was so expensive) }\end{array}$ & \\
\hline & & & $\begin{array}{l}\text { Saya tidak memiliki beasiswa Em... di } \\
\text { Malaysia dan Turki. } \\
\text { (I did not have Em... scholarship in } \\
\text { Malaysia and turkey) }\end{array}$ & \\
\hline & & & $\begin{array}{l}\text { Saya mendapat beasiswa di Universitas } \\
\text { Asyafiiyah Indonesia. } \\
\text { (I got scholarship in Asyafiiyah University } \\
\text { Indonesia) }\end{array}$ & \\
\hline
\end{tabular}

Dari Tabel 3 terlihat bahwa dia fasih ketika menjelaskan pengalamannya menggunakan bentuk lampau, dan dia bisa membedakan penggunaan kalimat bentuk 
Minkhatunnakhriyah, Fahriany, Albiansyah, Analisis Penggunaan Tata Bahasa dan Pemerolehan Bahasa Kedua Bahasa Inggris pada Mahasiswa Thailand

negatif menggunakan kata bantu yang benar, walaupun ada kesulitan untuk mempraktikkan bentuk lampau dalam bentuk kalimat negative, seperti dalam kutipan berikut:

"when I was in Thailand, I want to learn. I want to went out from Thailand. Firstly, I wanted to study at Malaysia and Turkey, but turkey was far away from Thailand and Malaysia was so expensive. I did not have Em... scholarship in Malaysia and turkey. I got scholarship in Asyafiiyah University Indonesia

"Ketika saya di Thailand, saya ingin belajar. Saya ingin keluar dari Thailand. Pertama, saya ingin belajar di Malaysia dan Turki, tetapi Turki jauh dari Thailand, dan Malaysia mahal sekali. Saya tidak punya Em... beasiswa di Malaysia dan Turki. Saya mendapat beasiswa di Asyafiiyah University Indonesia”.

\section{PEMBAHASAN}

Salah satu teori dari Tarigan (1990) menyebutkan bahwa proses memperoleh bahasa kedua yaitu secara sadar dan muncul dari faktor internal seperti motivasi untuk menguasainya. Analisis data menunjukkan bahwa informan mampu berbahasa Inggris dengan menggunakan tata bahasa yang sesuai. Oleh karena itu, penguasaan bahasa pada orang dewasa membutuhkan faktor internal dan eksternal seperti yang disebutkan oleh Sanz (2005). Berkaitan dengan teori penelitian ini, penguasaan bahasa kedua pada orang dewasa memerlukan kondisi yang tanggap sesuai dengan konteks pembelajaran tersebut. Dengan demikian, digunakan beberapa metode untuk meningkatkan penguasaan bahasa kedua. Selanjutnya Rod (1997) menyebutkan bahwa faktor internal dalam penguasaan bahasa kedua terdiri atas motivasi tinggi, kecerdasan, bakat, dan usia.

Aspek internal tersebut sangat berpengaruh dalam pengembangan bahasa kedua, khususnya dalam tata bahasa Inggris yang digunakan. Namun. Cahya \& Syam (2013) menyebutkan bahwa dalam teori Krashen, yang merupaan seorang ahli linguistik yang bertolak belakang dengan para ahli bahasa lainnya, inti dari pembelajaran bahasa adalah kemampuan untuk mengomunikasikan bahasa sasaran tanpa memperhatikan kaidah tata bahasa. Di sisi lain, aturan tata bahasa memiliki aspek yang penting, seperti yang dikatakan Hunston (2012) bahwa tata bahasa adalah 
bagaimana suatu kata digunakan, artinya tata bahasa membuat beberapa kata menjadi mudah dipahami dalam penggunaannya. Lebih lanjut, menurut Laura (2015) rata bahasa yaitu untuk mengungkapkan makna, menyusun kalimat, teks, dan berkomunikasi dengan penutur lain. Oleh karena itu, menguasai bahasa kedua, khususnya tata bahasa Inggris dalam berbicara sangat penting, dan diperlukan upaya lebih bagi orang yang menguasai bahasa asing.

Berkaitan dengan rumusan masalah penelitian ini, berdasarkan hasil wawancara dan analisis, dapat diketahui bahwa informan belum menguasai bahasa keduanya dengan fasih. Tata bahasa yang digunakan menggunakan tata bahasa sederhana dengan variasi yang sedikit. Informan tampak kesulitan terutama dalam hal penguasaan kosakata, sehingga ia juga merasakan sendiri kesulitannya dalam memproduksi atau berbicara bahasa Inggris.

\section{SIMPULAN}

Penelitian ini menghasilkan temuan bahwa pemerolehan bahasa kedua dapat dilakukan melalui aktivitas menonton film, mendengarkan, lagu dan membaca novel. Kegiatan ringan dan menarik ini dapat membantu meningkatkan kemampuan bahasa, terutama dalam memperkaya kosakata. Tidak ditemukan hasil yang signifikan dari hasil kegiatan tersebut untuk meningkatkan dan memperkaya penguasaan tata bahasa. Penelitian ini juga menemukan bahwa dalam produksi bahasa yang dituturkan oleh informan, terdapat lima variasi penggunaan tata bahasa sederhana. Meskipun kelimanya dapat dikuasai dengan baik, peneliti dapat menyimpulkan bahwa informan belum menguasai bahasa keduanya dengan baik.

\section{REFERENSI}

Beardsmore, H. B. (1982). Bilingualism. Tieto: Avon.

Bolton, K. (2018). World Englishes and Second Language Acquisition. World Englishers Journal 37(1), 5-18. doi:10.1111/weng.12299

Cahya, A., \& Syam, M. (2013). Pemerolehan Bahasa Kedua Menurut Stephen Krashen. At-Ta'dib Journal of Pesantren Education, 8(2), 265-279.

Chaer Abdul. (2009). Psikolinguistik kajian teoretik, Jakarta: Rineka Cipta.

Chomsky, N. (1972). Language and Mind. New York, NY: Harcourt Brace Jovanovich.

Copyright $\odot 2021$ Minkhatunnakhriyah, Fahriany, Albiansyah 
Minkhatunnakhriyah, Fahriany, Albiansyah, Analisis Penggunaan Tata Bahasa dan

Pemerolehan Bahasa Kedua Bahasa Inggris pada Mahasiswa Thailand

Dakin, J. W. (2018). Grammar Assessment. The TESOL Encyclopedia of English Language Teaching, 1-7. doi:10.1002/9781118784235.eelt0339

Derakhshan, A. (2015). The Interference of First Language and Second Language Acquisition. Academy publication, 5(10). https://doi.org/10.17507/tpls.0510.19

Dulay H, Burt M, Krashen S. 1982. Language Two. New York: Oxford University Press

Hunston, S. (2012). Pattern grammar. The encyclopaedia of applied linguistics, 1-6.

Krashen, S. D. (2002). Second Language Acquisition (1st ed.). Pergamon Press Inc.

Laura, Downing H (2015). grammar and evaluation. The Encyclopaedia of Applied Linguistics.

Nunan, David (1991). Research Methods in Language Learning. Cambridge: Cambridge University Press.

Ellis, R. (1997). Second Language Acquisition (1st ed.). Oxford University Press.

Sanz, C. (2005). Mind \& Context: Adult Second Language Acquisition. Georgetown university press.

Shirai Yasuhiro (2018). Connectionism and second language acquisition, Paris: Peter robinson. DOI:10.4324/9780203118085

Tarigan, Henry Guntur (1990). Berbicara sebagai suatu keterampilan Bahasa. Bandung: Angkasa

Thornbury, S. (1999). How to teach grammar (J. Harmer (ed.); 1st ed.). Bluestone Press, Charlbury, Oxfordshire, UK.

Wasow, T. (2017). Generative Grammar: Rule Systems for Describing Sentence Structure. In Aronoff \& Reese-Miller. eds. The Handbook of Linguistics, 119140. John Wiley \& Sons. doi: 10.1002/9781119072256.ch7. 